\title{
Phytotoxic Effects of Surface Ozone Exposure on Rice Crop-A Case Study of Tropical Megacity of India
}

\author{
Pallavi Saxena $^{1^{*}}$, Monojit Chakraborty ${ }^{2}$, Saurabh Sonwani ${ }^{3}$ \\ ${ }^{1}$ Department of Environmental Sciences, Hindu College, University of Delhi, New Delhi, India \\ ${ }^{2}$ Division of Climate Change and Environment, IORA Ecological Solutions, New Delhi, India \\ ${ }^{3}$ Department of Environmental Studies, Zakir Husain Delhi College, University of Delhi, New Delhi, India \\ Email: *pallavienvironment@gmail.com
}

How to cite this paper: Saxena, P., Chakraborty, M., \& Sonwani, S. (2020). Phytotoxic Effects of Surface Ozone Exposure on Rice Crop-A Case Study of Tropical Megacity of India. Journal of Geoscience and Environment Protection, 8, 322-334. https://doi.org/10.4236/gep.2020.85020

Received: April 22, 2020

Accepted: May 26, 2020

Published: May 29, 2020

Copyright $\odot 2020$ by author(s) and Scientific Research Publishing Inc. This work is licensed under the Creative Commons Attribution International License (CC BY 4.0).

http://creativecommons.org/licenses/by/4.0/

(c) (i) Open Access

\begin{abstract}
Increasing tropospheric ozone concentration is a big threat to food security due to its phytotoxicity. It causes a huge damage to crop production across the globe, especially in the $\mathrm{C}_{3}$ plants (paddy (Oryza sativa)). The present study focuses on exposure-plant response index over different $\mathrm{O}_{3}$ concentration. In this study, two metrics viz. the average ozone for $7 \mathrm{~h}$ during daytime (M7) and accumulated exposure above a threshold of X ppb (AOTX) have been used in examining crop yield decline in Delhi, India. Eight AOTX indices (AOT0, AOT5, AOT10, AOT15, AOT20, AOT25, AOT30 and AOT40) were analysed and potential crop reduction was predicted. The regular monitoring of $\mathrm{O}_{3}$ was done for 24 hours in year 2013. As per the European benchmark, a 5\% yield loss was expected when AOT40 values crosses $3000 \mathrm{ppb} \cdot \mathrm{h}$, however this study revealed that AOT40 threshold value ranged between 695 ppb to 17645 ppb which had exceeded the European benchmark in most of the months. The crop reduction was found to be $\sim 6.3 \%$ as evaluated by AOT40 index, whereas, total AOTX contributed up to $23 \%$ of rice yield reduction in Delhi NCR. On the other side, only $2 \%$ of rice yield loss has been predicted using M7 index, which is not comparable with AOTX indices. The M7 index was also found incomparable to the calculated net yield loss (13\%) for year 2013 to 2016. Hence, AOT40 may be a better index to predict the vulnerable impact of $\mathrm{O}_{3}$ into the crop production. The total vulnerability of $\mathrm{O}_{3}$ calculated as $57 \%$ in the crops reduction, while impacts of $\mathrm{O}_{3}$ was calculated and summed up for both the significant and non-significant paddy growing seasons. Hence, this study highlights an alarming situation in crop yield reduction due to $\mathrm{O}_{3}$ exposure in Delhi NCR which further threatens food security.
\end{abstract}




\section{Keywords}

Tropospheric Ozone, AOT40, M7, Paddy Yield, Relative Yield Loss

\section{Introduction}

Tropospheric ozone $\left(\mathrm{O}_{3}\right)$ is considered as the single-most deleterious phytotoxic air pollutant and has shown a tremendous negative effect on growth and production of crops in different parts of the world (Feng et al., 2008; Mills et al., 2011; Wild et al. 2011; Stevenson et al. 2013). This is also a major concern in a country like India where high urbanization and industrialization leads to increase in precursor gases which finally results in high generation of tropospheric $\mathrm{O}_{3}$ (Burney \& Ramanathan, 2014). This ozone is the result of reactions involved in photochemical smog formation in the troposphere. Ozone is also generated from its precursors like volatile organic compounds (VOCs), nitrogen oxides $\left(\mathrm{NO}_{\mathrm{x}}\right)$ and carbon monoxide (CO) in the presence of sunlight (Gurjar et al., 2016). Tropospheric $\mathrm{O}_{3}$ is recorded as the most harmful air pollutant in North America, Japan and Europe (Sharma et al., 2017). In contrast with the past, over the last decade, $\mathrm{O}_{3}$ is also found to be very high in large areas of Asian developing countries (Mills et al., 2007; Michael et al., 2013). Ozone is a powerful oxidant which results in a number of health impacts (Rai et al., 2007; Saxena \& Sonwani, 2020), for instance, oxidative stress (Sinha et al., 2015; Saxena et al., 2016) and irritation in the lungs (Garg et al., 2015). In context of plants, various common crop species are sensitive to $\mathrm{O}_{3}$, therefore exposure to $\mathrm{O}_{3}$ leads to decline in crop yields and resulted in lower crop quality (Debaje, 2014; Klingberg et al., 2014). Several studies have been reported so far about crop yield impacts and photosynthetic activities by $\mathrm{O}_{3}$ exposure (Krupa et al., 1994; Chameides et al., 1999; Rai et al., 2007; Burney \& Ramanathan, 2014). It also causes an imbalance in redox status which produces early senescence. That's why, any basis that might raise the level of plant metabolites interaction with antioxidant capacity will also be responsible for increasing the adverse impact of $\mathrm{O}_{3}$ on crop plants (Fagnano et al., 2009; Saxena \& Sonwani, 2019). Due to the global rise in tropospheric ozone, the cost of agricultural losses is projected to reach about 35 million USD by the year 2030 (Avnery et al., 2011). The National Crop Loss Assessment Network (NCLAN) program is the nodal agency which implements permissible limit for studying the impacts of $\mathrm{O}_{3}$ on crop yield using open-top chamber (OTC) experiments (Avnery et al., 2011). NCLAN results depicted that decreased yearly soybean and cotton yield were $10 \%$ and $12 \%$ respectively when seasonal mean $\mathrm{O}_{3}$ mixing ratios were found to be greater than $50 \mathrm{ppb}$ (Klingberg et al., 2014). Fuhrer et al. (1997) found that a 10\% reduction was found in spring wheat crop when $\mathrm{O}_{3}$ crosses $40 \mathrm{ppb}$ concentration in Southern Europe. Different ozone indices are used to estimate the threshold effects which include AOTX $(0,10,20$, $30,40,50,60)$, SUM06, W126, M7 or M12, POD0 or POD10. The AOT40 is a 
cumulative exposure index, which is obtained by the sum of differences between the hourly concentration of $\mathrm{O}_{3}$ (in ppb) and permissible limit i.e. $40 \mathrm{ppb}$ in each hour when its value raises above $40 \mathrm{ppb}$ (UNECE, 1999). The SUM06 is the sum of hourly $\mathrm{O}_{3}$ mixing ratios which goes above the permissible limit of $60 \mathrm{ppb}$ all around the growing season and sunlight hours. The W126 index evaluates each hourly value by a sigmoidal weighting method so that the lower $\mathrm{O}_{3}$ values are also taken into consideration. Among them, AOT40 and SUM06 are generally used to measure crop loss due to ozone exposure in Europe and USA, respectively. Lastly M7 is, calculated for the whole cropping period by the average hourly $\mathrm{O}_{3}$ mixing ratio (ppb) during daytime hours between 0900 and $1600 \mathrm{~h}$ (Adams et al. 1989; Lesser et al. 1990; Lal et al., 2017). AOT40 is considered as the best linear fit between exposure to ozone concentration and decrease in crop yield. As per the European guidelines, if the accumulated ozone concentration under threemonth duration is exceeding $3000 \mathrm{ppb} \cdot \mathrm{h}$, then approximately 5\% reduction in crop yield is expected (Ishi et al., 2007). Various studies have been reported so far regarding solutions in terms of the correlation between AOTX and crop responses, particularly connecting this index with the level of $\mathrm{O}_{3}$-damage to vegetation. In a developing country like India, recent studies so far have suggested a net reduction in agricultural production due to $\mathrm{O}_{3}$, both using model-simulated studies (Van Dingenen et al., 2009; Avnery et al., 2011; Ghude et al., 2014) or based on some data derived from selected sites (Debaje, 2014; Sinha et al., 2015). Very few studies have been reported on $\mathrm{O}_{3}$ metrics, AOT40, AOTX indices, M7 or M12 indexes in India which can estimate the reduction in crop yield and loss in the agricultural sector. Therefore, the present study focuses on crop yield reduction of one of the staple crop of India i.e. rice by AOTX and M7 indices. In the case of rice, AOTX and M7 indices are more preferential to use as compared to other crops (Debaje, 2014; Sinha et al. 2015 and Lal et al., 2017). Hence, this study designed to evaluate and predict the loss in rice yield considering the Indian climate particularly in Delhi NCR by using AOTX and M7.

\section{Methodology}

\subsection{Study Area Description}

Delhi, India $\left(28.38^{\circ} \mathrm{N}, 77.10^{\circ} \mathrm{E}\right)$, lies in between the Indo-Gangetic Plain (IGP) in the east direction and semi-arid range of land of Rajasthan to the southwest. It constitutes an administrative area of $1483 \mathrm{~km}^{2}$ and is part of the bigger National Capital Region (NCR) having a total area of $54,984 \mathrm{~km}^{2}$. Delhi also faces high traffic density in part due to high influx of immigrants from other Indian cities and daily commuters from the NCR region i.e. Ghaziabad, Gurugram and Faridabad. It is one of the most populated city, with approximately 16.7 million people and is highly polluted (vehicle population = approximately 7.4 million) especially in terms of aerosols (Tiwari et al., 2013). The city experiences three main seasons viz. summer, monsoon, and winters. Winters cover the months of November till February, summers span from March to June and monsoon sea- 
son is from July to September.

\subsection{Ozone Monitoring}

The ozone data were collected continuously at Wazirabad, Delhi, India $\left(28.7336^{\circ} \mathrm{N}\right.$, $77.2190^{\circ} \mathrm{E}$ ). This site is located near to Yamuna Floodplain and has extensive paddy cultivation. This site is also a heavy traffic intersection area and hence traffic density is very high especially during the peak hours. Regular monitoring was done from January to December 2013 and data was recorded on an hourly basis for 24 hours every day. Ozone concentrations were monitored using a UV based Absorption Ozone Analyser (Environnment S.A. Model $\mathrm{O}_{3} 42 \mathrm{M}$, France). This instrument is based on Beer-Lambert's Law which measures sensitive values of ozone in ambient air.

\subsection{Crop Selection}

Rice (Oryza sativa) was selected as a study crop and it was used to estimate the amount of reduction recorded in its crop yield. Rice or paddy is one of the main Kharif crops and hence, chosen for the present study. The sowing of rice starts at the end of May in Kerala i.e. particularly in the start-up of the south-west monsoon season. But, sowing dates vary accordingly with the pattern of movement of rains and hence, in Northern part of India i.e. in Delhi, Kharif season normally includes sowing during July and is harvested by end of October or November.

\subsection{Mathematical Models}

AOTX is an analytical tool which is evaluated as the sum of differences between concentration, $X \mathrm{ppb}$ and the hourly ozone concentration, exceeding $X \mathrm{ppb}$, for each sunlight hour with solar radiation higher than $50 \mathrm{~W} / \mathrm{m}^{2}$ for a period of 3 months.

The formula to calculate AOTX is:

$$
\mathrm{AOTX}=\sum_{i=1}^{n}\left[C_{O 3}-X\right] \text { i for } C_{O 3}>X \mathrm{ppb}
$$

where $C_{O 3}$ is the hourly ozone concentration in ppb, $i$ is the running index, and $n$ is the number of hours along with $C_{O 3}$ higher than $X \mathrm{ppb}$, during the time evaluation (Grunhage et al., 1999).

$$
M 7=\frac{1}{n} \sum_{i=0}^{n}\left[C_{O 3}\right]
$$

From $n=0900$ and $1600 \mathrm{~h}$.

To obtain the suitable AOTX index in Delhi, firstly the approximate value of ozone concentration is evaluated. Due to fewer number of studies on impacts of ozone on crop production in Delhi, there are no available statistics that can be applied in this study. So, one of the methods is used to divide the permissible value for each AOTX index with total of ozone concentration. This value is supposed to be of initial crop reduction probably happen due to ozone exposure. 
Hence, the amount of paddy reduction in terms of percentage for each AOTX index is calculated by the following formula:

$$
\text { Calculated paddy reduction }(\%)=\frac{\text { AOTX value }}{\Sigma O \text { zone concentration }} \times \text { Paddy Production (3) }
$$

where, $\mathrm{X}$ is the index of AOT.

As India doesn't have indicators for estimation of decline in crop yield from ozone exposure, an analysis by AOTX indices should be carried out. As per European benchmark where $5 \%$ loss in yield for any agricultural crops will be expected to occur if the accumulated ozone concentration within that period is higher than $3000 \mathrm{ppb} \cdot \mathrm{h}$, (Ishii et al., 2007), the similar critical limit was used to distinguish the variation of responses between European and Indian region. Therefore, Equation (4) is used to identify the possible crop loss that likely to occur for each AOTX index in Delhi. In this analysis, $3000 \mathrm{ppb} \cdot \mathrm{h}$ was used as the significant level, similar to the European concentration-based critical level (Manual, 2004).

$$
\text { Estimated Crop Reduction }(\%)=\frac{\text { Calculated Crop Reduction }(\%)}{\text { Total AOTX }(\mathrm{ppb} \cdot \mathrm{h})} \times 3000 \mathrm{ppb} \cdot \mathrm{h}
$$

where, $3000 \mathrm{ppb} \cdot \mathrm{h}$ is the European standard for the AOT40 index (UNECE, 1996). Therefore, to determine the loss of the crops for all AOTX indexes, 3000 $\mathrm{ppb} \cdot \mathrm{h}$ is used as the standard consistent with the European critical level.

Moreover, the crop response functions for relative yields (RYs) for rice can also be calculated by the following formulas (Adams et al. 1989; Mills et al. 2007):

$$
\begin{gathered}
\mathrm{RY}=-0.0000039 \times \mathrm{AOT} 40+0.94 \\
\mathrm{RY}=e-(M 7 / 202)^{2.47} / e-(25 / 202)^{2.47}
\end{gathered}
$$

The relative yield loss (RYL) is calculated by

$$
\mathrm{RYL}=1.0-\mathrm{RY}
$$

\section{Results and Discussion}

The year-long study in Delhi revealed that the tropospheric $24 \mathrm{~h}$ averaged $\mathrm{O}_{3}$ concentrations vary from 15 to $40 \mathrm{ppb}$. However, day time-averaged concentrations touched the high notch as $54 \mathrm{ppb}$ during the month of April and May. Prolonged exposure to high levels of $\mathrm{O}_{3}$ may lead to damage to vegetation with possible relevant reductions in agricultural crop yields (Agrawal et al. 2003; Saxena \& Sonwani, 2019; Mills et al., 2007). The quantitative impacts analysis of $\mathrm{O}_{3}$ has been reciprocated with different $\mathrm{O}_{3}$ indexes, AOTX i.e. AOT0, AOT5, AOT10, AOT15, AOT20, AOT25, AOT30 and AOT40 in 2013 in Delhi at Wazirabad site were summarized in Table 1 . These are the accumulated $\mathrm{O}_{3}$ concentrations over a threshold of $0,5,10,15,25,30$ and $40 \mathrm{ppb}$ respectively. The 
Table 1. Summary of ozone concentration's threshold ozone indices in Delhi during the year 2013.

\begin{tabular}{llllllllll}
\hline Month & AOT0 & AOT5 & AOT10 & AOT15 & AOT20 & AOT25 & AOT30 & AOT40 & M7 \\
\hline Jan-Mar & 57,654 & 38,765 & 28,765 & 23,176 & 18,769 & 14,547 & 10,876 & 7685 & 31.02 \\
Apr-Jun & 81,497 & 57,232 & 50,674 & 43,969 & 36,946 & 30,024 & 23,078 & 17,645 & 49.26 \\
July-Sept & 38,065 & 23,958 & 18,428 & 13,537 & 9341 & 5983 & 3386 & 695 & 28.63 \\
Oct-Dec & 61,366 & 35,454 & 29,485 & 23,640 & 18,079 & 13,203 & 9070 & 3369 & 35.20 \\
\hline
\end{tabular}

various threshold values which were produced in Table 1 were important to depict the range of threshold values at Wazirabad, Delhi, which will consequently be used to estimate the crucial level of the AOTX index. Different AOTX index give different threshold values and hence they are important to analyze for the same. In Table 1, it has been shown that the AOT40 threshold value ranged between $695 \mathrm{ppb} \cdot \mathrm{h}$. to $17645 \mathrm{ppb} \cdot \mathrm{h}$. As per the European standard, permissible limit which is higher than $3000 \mathrm{ppb} \cdot \mathrm{h}$ covering a 3 months period is expected to result in an approximate 5\% crop reduction. As per the estimated range of ozone limit concentration of $40 \mathrm{ppb}$ in Delhi, it is largely affected by the ozone concentration of $5 \%-30 \%$ due to the increase in the concentration of accumulated ozone exposure i.e. up to $18,000 \mathrm{ppb} \cdot \mathrm{h}$.

On the contrary, another exposure plant response index, M7 has shown values as high $63 \mathrm{ppb}$ in May and as low as $25 \mathrm{ppb}$ in July. The M7 value during the Kharif season was calculated to be $32 \mathrm{ppb}$, almost similar value as reported by Lal et al., 2017 for the north Indian region (Table 1). It has been observed that the statistical correlation between 24-h average monthly $\mathrm{O}_{3}$ and monthly average M7 as well as correlations between monthly average AOT40 and monthly average $\mathrm{M} 7$ are very poorly fitted $\left(\mathrm{R}^{2}=0.47 \& \mathrm{R}^{2}=0.27\right.$, respectively). However, the relations among day time average $\mathrm{O}_{3}$ concentration, monthly average $\mathrm{M} 7$, and monthly average AOT40 have been found slightly better $\left(R^{2}=0.67 \& R^{2}=0.45\right.$, respectively). This has been observed that the $\mathrm{M} 7$ index value was lower i.e. 32 ppb during the paddy season/significant season (July to November) than the value i.e. $38 \mathrm{ppb}$, was found during the non-paddy season/non-significant season (December to June). Moreover, during paddy season, the estimated crop reduction calculated by M7 was found to be $2 \%$ while in non-paddy season the total crop reduction was calculated as $11.2 \%$.

The analysis on the effect of AOTX indexes in paddy reduction was performed in both significant and non-significant seasons. Figure 1(a) and Figure 1(b) shows the correlation between AOTX indexes and paddy reduction as per the Indian scenario of climate for two periods in the year 2013. In Figure 1(a) and Figure 1(b), there are two subsequent patterns between the AOTX indexes and paddy reduction in the Delhi (Indian) climate. As per observations, during both the periods, AOT0 gave the least paddy reduction while AOT40 reported the maximum loss in paddy. The highest percentage for paddy reduction was found to be $76.45 \%$, depicted by the AOT40 index during the non-significant 


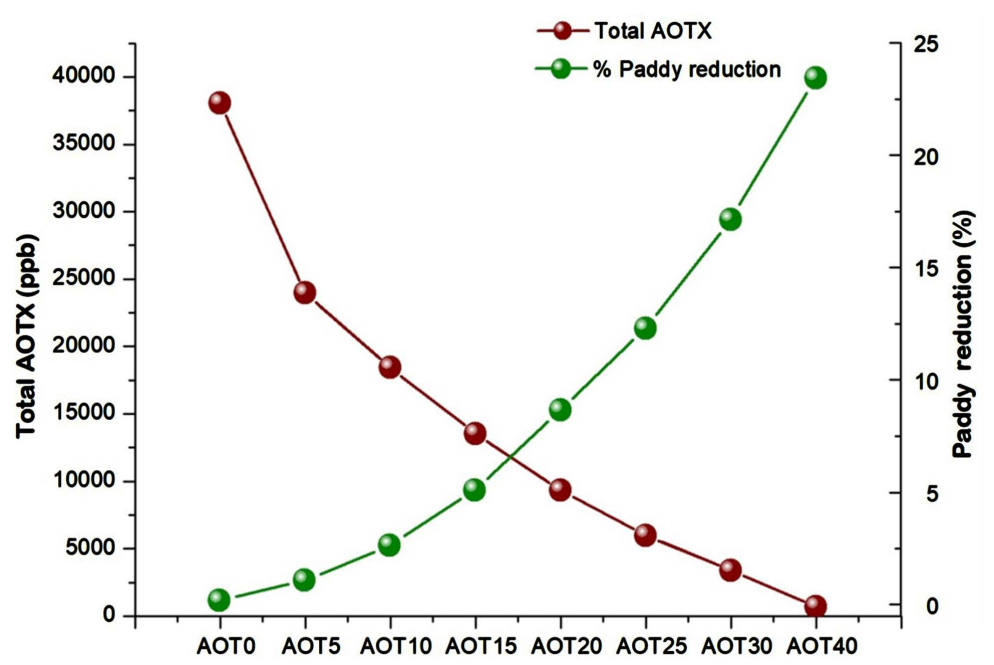

(a)

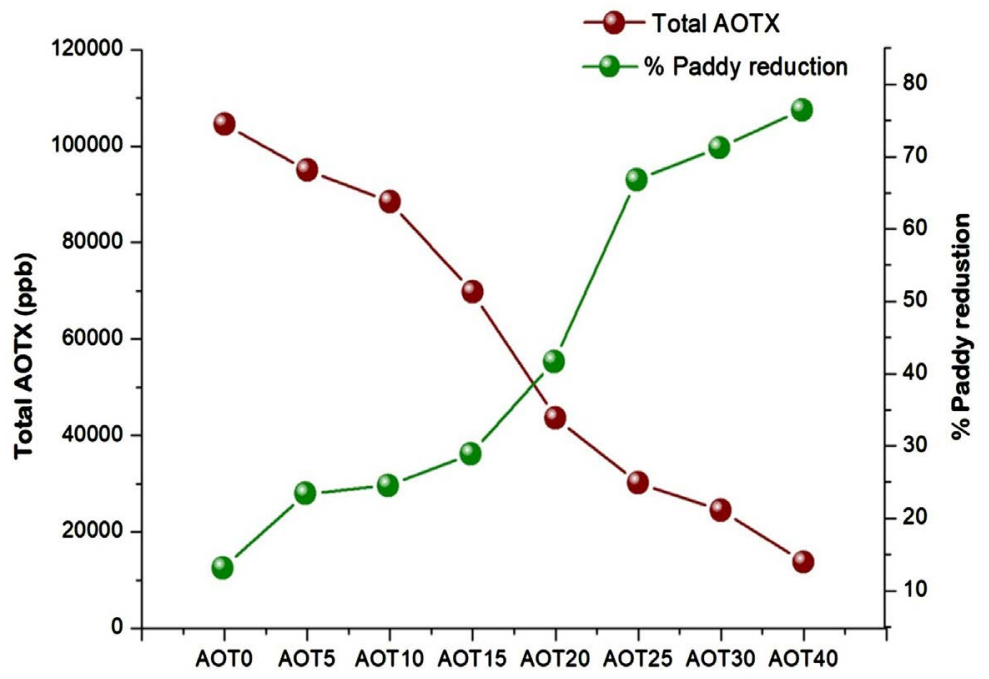

(b)

Figure 1. (a) Significant season and (b) Non-significant season: Relationship between AOTX indexes and paddy reduction in Delhi, India.

season. In India especially in Northern India (one of them in Delhi NCR) where paddy production was mostly influenced by ozone exposure during the nonsignificant season (Figure $1(\mathrm{~b})$ ).

During this season, Delhi NCR experiences lower boundary layer, low-temperature inversions, high relative humidity and low wind speed with less rainfall as compared to other months (Lal et al., 2017; Saxena \& Kulshrestha, 2016). These conditions are favorable for high ozone concentrations during winters while in early summers high temperature and high sunlight intensity favor high ozone concentrations (Bhuyan et al., 2014). The most favorable season for sowing of rice is during monsoon season. This season acts as a scavenging agent which cleans up the pollutants present in the atmosphere due to heavy rainfall, high relative humidity, and high wind velocity. This is the main reason that ozone concentrations during this season are very low (Ghosh et al., 2013). 
Although this occurrence will decline the rate of ozone conversions but higher humidity and moderate temperatures can give rise to higher stomatal conductance. Consequently, the ozone uptake by plant leaves results in a loss of yield (Mohammed et al., 2013). This is a clear indication that paddy crop reduction had occurred during the significant season, though the percentage reduction was less than in the non-significant season.

Statistical correlation associations between paddy reduction and AOTX indexes in 2013 are shown in Table 2. As observed, the AOT40 index has got the highest $\mathrm{R}^{2}$ value as compared to the other indexes. Mohammed et al. (2013), had compared several AOTX indexes i.e. AOT15, AOT20, АOT25, АОT30, and AOT50 in Malaysia to determine the impact of different indexes on paddy. They found that AOT50 index had provided the best fit correlation between the index and crop i.e. paddy response. Hence, as per the variation of different indexes, the crop response would vary. Apart from this study, several studies find that AOT40 index has the best fit when considering the crop response (Rai et al., 2007; Beig et al., 2008; Debaje, 2014; Ghude et al., 2014; Sinha et al., 2015). A similar observation has been obtained in our present study which compare all the indices with paddy response, with AOT40 having the best paddy reduction response. For example, $16.3 \%$ of relative yield loss of paddy was reported by Ghude et al. (2008) in Delhi region by using AOT40 index. Another study was reported by Lal et al., (2017), where $0.3 \%$ and $6.3 \%$ of paddy reduction was found in total of different parts of India by using M7 and AOT40 respectively. This present study also reported that AOT40 is having the best paddy reduction response of approximately $6.3 \%$ in Delhi region.

Figure 2 depicts the approximate percentage of paddy reduction for each AOTX index in Delhi climate (Indian tropical). This has been widely accepted if the cumulative tropospheric $\mathrm{O}_{3}$ concentration will exceed the limit of $3000 \mathrm{ppb} \cdot \mathrm{h}$ in a particular crop growing season and only then conspicuous yield loss can be seen (Kärenlampi \& Skärby, 1996; Beig et al., 2008). During our research, the

Table 2. $\mathrm{R}^{2}$ value for the Relationship of AOTX and M7 indices with Paddy Reduction in Wazirabad, Delhi.

\begin{tabular}{ccc}
\hline AOTX indexes & Coefficient of determination $\left(\mathrm{R}^{2}\right)$ & Equation $(y=$ paddy reduction $)$ \\
\hline AOT0 & 0.78 & $y=13,612+0.7633 x$ \\
AOT5 & 0.80 & $y=14,671+1.0212 x$ \\
AOT10 & 0.81 & $y=12,243+1.663 x$ \\
AOT15 & 0.86 & $y=10,133+1.732 x$ \\
AOT20 & 0.88 & $y=8613.3+1.967 x$ \\
AOT25 & 0.92 & $y=8412.4+2.167 x$ \\
AOT30 & 0.93 & $y=8316.6+3.22 x$ \\
AOT40 & 0.93 & $y=11,671+5.13 x$ \\
M7 & 0.46 & $y=3287.7 x-90194$
\end{tabular}




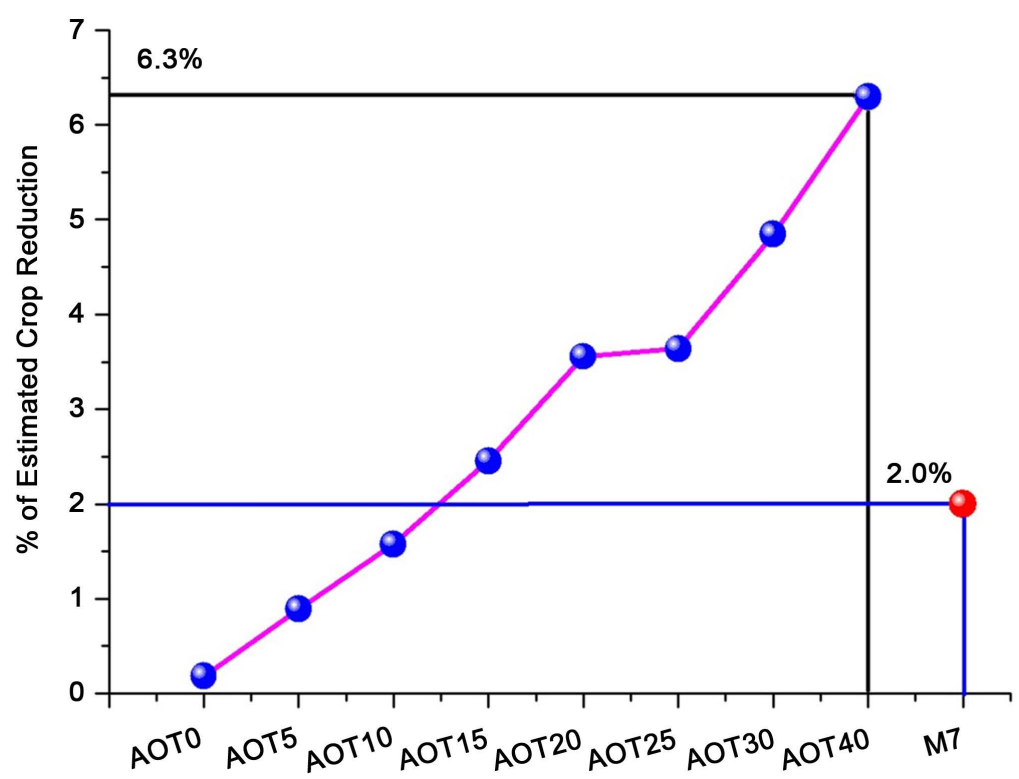

Figure 2. Estimated paddy reduction due to ozone exposure over three months by each AOTX and M7 indexes.

cumulative $\mathrm{O}_{3}$ concentration was found to be more than 14,000 ppbh, which is far exceeded value than the critical level. Therefore, reduction in paddy was calculated as $6.3 \%$ by AOT40, which is much higher value than the AOT40 calculated by the critical value as $3000 \mathrm{ppb} \cdot \mathrm{h}$. Table 2 results also support this fact, as the AOT40 index fits best with the Indian climate as compared to other indexes. The obtained percentage reduction i.e. $6.3 \%$ is different from the European benchmark which is only $5 \%$. Thus, in the Indian climate, especially in an urban area like Delhi NCR, there is a high percentage crop (paddy) reduction and it is different from the European benchmark.

Relative Yield Loss (RYL) of rice has also been calculated as 0.23 of RYL in the Delhi NCR region at Wazirabad site which is a quite comparable to the value of 0.29 as reported in Lal et al., (2017). Earlier studies reported in India on RYL of rice had also reported the similar values (Debaje, 2014; Sinha et al., 2015; Ghude et al., 2014; Van Dingenen et al., 2009). This value is alarming for agricultural scientists as ozone exposure in Delhi NCR is much high and is highly affecting the crop production in Delhi and its nearby areas. The total yield loss of rice has been estimated by using the AOT40 index and is found to be $0.16 \mathrm{Mt}(6 \%)$ of 2.6 Mt rice produced in Delhi NCR (Table 3). In comparison, the total AOTX contributed to a huge rice yield loss of $0.61 \mathrm{Mt}(23 \%)$. On the contrary, M7 index contributed to the rice yield loss of only $0.06 \mathrm{Mt}(2 \%)$. Therefore, the study has shown a clear impact of $\mathrm{O}_{3}$ phytotoxicity on rice yield. The indices used to calculate the entire range of crop yield losses, shows that $2 \%$ to $23 \%$ losses of crop yield occur in Delhi NCR. This has been validated with the rice production data from ICAR (2018) which finds a decrease of up to $13 \%$ from 2013 to 2016 in the Delhi NCR. Similar study was conducted by Ghude et al. (2008), where, $16.3 \%$ of relative yield loss of paddy was reported in Delhi region by using AOT40 index. 
Table 3. Loss of paddy by relative yield loss with respect to AOT40 and M7 in Delhi-NCR of 2013 (Source: ICAR reporter, 2018).

\begin{tabular}{|c|c|c|c|c|c|c|c|c|}
\hline \multirow{2}{*}{$\begin{array}{l}\text { National Capital } \\
\text { Region (districts) }\end{array}$} & \multirow{2}{*}{$\begin{array}{l}\mathrm{Avg} \mathrm{O}_{3} \\
(\mathrm{ppb})\end{array}$} & \multirow{2}{*}{$\begin{array}{c}\text { Avg } \\
\text { AOT40 } \\
(\mathrm{ppb} \cdot \mathrm{h})\end{array}$} & \multirow{2}{*}{$\begin{array}{c}\text { Avg M7 } \\
(\mathrm{ppb})\end{array}$} & \multirow{2}{*}{$\begin{array}{c}\text { RYL } \\
\text { AOT40 }\end{array}$} & \multirow{2}{*}{$\begin{array}{l}\text { RYL } \\
\text { M7 }\end{array}$} & \multirow{2}{*}{$\begin{array}{l}\text { Paddy } \\
\text { Yield (t) }\end{array}$} & \multicolumn{2}{|c|}{ Paddy loss (t) } \\
\hline & & & & & & & AOT40 & M7 \\
\hline Delhi (7) & & & & & & 29,652 & 1779 & 593 \\
\hline Haryana (10) & & & & & & $2,153,000$ & 129,180 & 43,060 \\
\hline Uttar Pradesh (7) & 19 & 318 & 32 & 0.06 & 0.02 & 452,250 & 27,135 & 9045 \\
\hline Rajasthan (2) & & & & & & 4259 & 256 & 85 \\
\hline Total & & & & & & $2,639,161$ & 158,350 & 52,783 \\
\hline
\end{tabular}

\section{Conclusion}

The present study highlighted that paddy crop reduction was higher during the non-significant season as compared to a significant season. This study also demonstrates that among all the selected AOTX and M7 indexes, AOT40 is highly responsible for paddy reduction as compared to the rest. To further support this statement, linear regression analysis confirms that AOT40 best fits in the context of Indian climate particularly Delhi. Thus, this study suggests that the AOT40 is the most appropriate index especially in comparison to M7 while evaluating potential ozone effects on crops in the tropical regions. The marked distinction in the values of AOTX indices in Europe and India is due to the variation in climatic conditions and availability of longer daylight hours in India. In addition to that, it has also been reported that AOT40 index evaluated $6.3 \%$ of paddy reduction which was higher than $3000 \mathrm{ppb} \cdot \mathrm{h}$ over three months of the growing season. This result coincided with the European guidelines, which indicates that at least $5 \%$ crop reduction would be expected. By taking the overall view of crop loss due to ozone exposure in India, some changes can be made in the modification of AOTX indexes. If AOT40 is used as the index, this study indicates that the approximate crop reduction must be shifted from $5 \%$ to $6.3 \%$. Moreover, it has been expected that as per the AOT40 index the total yield loss of rice would be $0.16 \mathrm{Mt}$ (6\%) of 2.6 Mt rice produced in Delhi NCR. Whereas, the total AOTX contributed huge rice yield loss as $0.61 \mathrm{Mt}$ i.e. $23 \%$ of the total rice produced. On the contrary, M7 index contributed to the rice yield loss as $0.06 \mathrm{Mt}(2 \%)$, which may does not truly fit for Delhi NCR or the tropical climate and the net crop yield loss calculated as 13\% during the year 2013 to 2016. Therefore, the study has shown a clear impact of $\mathrm{O}_{3}$ phytotoxicity on rice yield over Delhi NCR. As paddy is the main crop of India, a decreasing paddy production in the future may negatively impact the agriculture sector, particularly in Delhi.

\section{Acknowledgements}

The authors pay sincere thanks to National Environmental Engineering Research Institute (NEERI), New Delhi for providing the instrumentation facility. 


\section{Conflicts of Interest}

The authors declare that they have no conflict of interest.

\section{References}

Adams, R. M., Glyer, J. D., Johnson, S. L., \& McCarl, B. A. (1989). A Reassessment of the Economic Effects of Ozone on US Agriculture. JAPCA, 39, 960-968. https://doi.org/10.1080/08940630.1989.10466583

Agrawal, M., Singh, B., Rajput, M., Marshall, F., \& Bell, J. N. B. (2003). Effect of Air Pollution on Peri-Urban Agriculture: A Case Study. Environmental Pollution, 126, 323-329. https://doi.org/10.1016/S0269-7491(03)00245-8

Avnery, S., Mauzerall, D. L., Liu, J., \& Horowitz, L. W. (2011). Global Crop Yield Reductions Due to Surface Ozone Exposure: 1. Year 2000 Crop Production Losses and Economic Damage. Atmospheric Environment, 45, 2284-2296. https://doi.org/10.1016/j.atmosenv.2010.11.045

Beig, G., Ghude, S. D., Polade, S. D., \& Tyagi, B. (2008). Threshold Exceedances and Cumulative Ozone Exposure Indices at Tropical Suburban Site. Geophysical Research Letters, 35, L02802. https://doi.org/10.1029/2007GL031434

Bhuyan, P. K., Bharali, C., Pathak, B., \& Kalita, G. (2014). The Role of Precursor Gases and Meteorology on Temporal Evolution of $\mathrm{O}_{3}$ at a Tropical Location in Northeast India. Environmental Science and Pollution Research, 21, 6696-6713. https://doi.org/10.1007/s11356-014-2587-3

Burney, J., \& Ramanathan, V. (2014). Recent Climate and Air Pollution Impacts on Indian Agriculture. Proceedings of the National Academy of Sciences, 111, 16319-16324. https://doi.org/10.1073/pnas.1317275111

Chameides, W. L., Xingsheng, L., Xiaoyan, T., Xiuji, Z., Luo, C., Kiang, C. S., et al. (1999). Is Ozone Pollution Affecting Crop Yields in China? Geophysical Research Letters, 26, 867-870. https://doi.org/10.1029/1999GL900068

Debaje, S. B. (2014). Estimated Crop Yield Losses Due to Surface Ozone Exposure and Economic Damage in India. Environmental Science and Pollution Research, 21, 73297338. https://doi.org/10.1007/s11356-014-2657-6

Fagnano, M., Maggio, A., \& Fumagalli, I. (2009). Crops' Responses to Ozone in Mediterranean Environments. Environmental Pollution, 157, 1438-1444. https://doi.org/10.1016/j.envpol.2008.09.001

Feng, Z., Kobayashi, K., \& Ainsworth, E. A. (2008). Impact of Elevated Ozone Concentration on Growth, Physiology, and Yield of Wheat (Triticum aestivum L.): A Meta-Analysis. Global Change Biology, 14, 2696-2708. https://doi.org/10.1111/j.1365-2486.2008.01673.x

Fuhrer, J., Skärby, L., \& Ashmore, M. R. (1997). Critical Levels for Ozone Effects on Vegetation in Europe. Environmental Pollution, 97, 91-106. https://doi.org/10.1016/S0269-7491(97)00067-5

Garg, A., Saxena, P., \& Ghosh, C. (2015). Evaluation of Tolerance and Sensitivity of Selected Plant Species with Special Reference to Gasoline Exhaust Pollution. International Journal of Scientific \& Technology Research, 4, 199-207.

Ghosh, D., Lal, S., \& Sarkar, U. (2013). High Nocturnal Ozone Levels at a Surface Site in Kolkata, India: Trade-Off between Meteorology and Specific Nocturnal Chemistry. Urban Climate, 5, 82-103. https://doi.org/10.1016/j.uclim.2013.07.002

Ghude, S. D., Jain, S. L., Arya, B. C., Beig, G., Ahammed, Y. N., Kumar, A., \& Tyagi, B. 
(2008). Ozone in Ambient Air at a Tropical Megacity, Delhi: Characteristics, Trends and Cumulative Ozone Exposure Indices. Journal of Atmospheric Chemistry, 60, 237252. https://doi.org/10.1007/s10874-009-9119-4

Ghude, S. D., Jena, C., Chate, D. M., Beig, G., Pfister, G. G., Kumar, R., \& Ramanathan, V. (2014). Reductions in India's Crop Yield Due to Ozone. Geophysical Research Letters, 41, 5685-5691. https://doi.org/10.1002/2014GL060930

Grünhage, L., Jäger, H. J., Haenel, H. D., Löpmeier, F. J., \& Hanewald, K. (1999). The European Critical Levels for Ozone: Improving Their Usage. Environmental Pollution, 105, 163-173. https://doi.org/10.1016/S0269-7491(99)00029-9

Gurjar, B. R., Ravindra, K., \& Nagpure, A. S. (2016). Air Pollution Trends over Indian Megacities and Their Local-to-Global Implications. Atmospheric Environment, 142, 475-495. https://doi.org/10.1016/j.atmosenv.2016.06.030

ICAR Reporter (2018). https://icar.org.in/sites/default/files/IR-April-June-2018Web.pdf

Ishii, S., Bell, J. N. B., \& Marshall, F. M. (2007). Phytotoxic Risk Assessment of Ambient Air Pollution on Agricultural Crops in Selangor State, Malaysia. Environmental Pollution, 150, 267-279. https://doi.org/10.1016/j.envpol.2007.01.012

Kärenlampi, L., \& Skärby, L. (Eds.) (1996). Critical Levels for Ozone in Europe: Testing and Finalising the Concepts. Kuopio: University of Kuopio.

Klingberg, J., Engardt, M., Karlsson, P. E., Langner, J., \& Pleijel, H. (2014). Declining Ozone Exposure of European Vegetation under Climate Change and Reduced Precursor Emissions. Biogeosciences, 11, 5269-5283. https://doi.org/10.5194/bg-11-5269-2014

Krupa, S. V., Nosal, M., \& Legge, A. H. (1994). Ambient Ozone and Crop Loss: Establishing a Cause-Effect Relationship. Environmental Pollution, 83, 269-276. https://doi.org/10.1016/0269-7491(94)90147-3

Lal, S., Venkataramani, S., Naja, M., Kuniyal, J. C., Mandal, T. K., Bhuyan, P. K., et al. (2017). Loss of Crop Yields in India Due to Surface Ozone: An Estimation Based on a Network of Observations. Environmental Science and Pollution Research, 24, 2097220981. https://doi.org/10.1007/s11356-017-9729-3

Lesser, V. M., Rawlings, J. O., Spruill, S. E., \& Somerville, M. C. (1990). Ozone Effects on Agricultural Crops: Statistical Methodologies and Estimated Dose-Response Relationships. Crop Science, 30, 148-155.

https://doi.org/10.2135/cropsci1990.0011183X003000010033x

Manual, M. (2004). Manual on Methodologies and Criteria for Modelling and Mapping Critical Loads and Levels and Air Pollution Effects, Risks and Trends. In: Mapping Manual UNECE Convention on Long-Range Transboundary Air Pollution (LRTAP) (251 p). Geneva: UNECE.

Mills, G., Buse, A., Gimeno, B., Bermejo, V., Holland, M., Emberson, L., \& Pleijel, H. (2007). A Synthesis of AOT40-Based Response Functions and Critical Levels of Ozone for Agricultural and Horticultural Crops. Atmospheric Environment, 41, 2630-2643. https://doi.org/10.1016/j.atmosenv.2006.11.016

Mills, G., Hayes, F., Simpson, D., Emberson, L., Norris, D., Harmens, H., \& Büker, P. (2011). Evidence of Widespread Effects of Ozone on Crops and (Semi-) Natural Vegetation in Europe (1990-2006) in Relation to AOT40- and Flux-Based Risk Maps. Global Change Biology, 17, 592-613. https://doi.org/10.1111/j.1365-2486.2010.02217.x

Mohammed, N. I., Ramli, N. A., \& Yahya, A. S. (2013). Ozone Phytotoxicity Evaluation and Prediction of Crops Production in Tropical Regions. Atmospheric Environment, 68, 343-349. https://doi.org/10.1016/j.atmosenv.2012.09.010

Rai, R., Agrawal, M., \& Agrawal, S. B. (2007). Assessment of Yield Losses in Tropical 
Wheat Using Open Top Chambers. Atmospheric Environment, 41, 9543-9554. https://doi.org/10.1016/j.atmosenv.2007.08.038

Saxena, P. Sonwani, S. \& Kulshrestha, U.C. (2016). Impact of Tropospheric Ozone and Particulate Matter on Plant Health. In D. Pandey, \& A. Sarkar (Eds.), Sustaining Future Food Security in Changing Environments (pp. 19-60). UK: Nova Science Publisher.

Saxena, P., \& Kulshrestha, U.C. (2016). Contribution of Carbonaceous Species in SOA Formation during Fog and Non-Fog Period. Journal of Chemical Biological Physical Science, 7, 31-48.

Saxena, P., \& Sonwani, S. (2019). Criteria Air Pollutants and Their Impact on Environmental Health. Singapore: Springer. https://doi.org/10.1007/978-981-13-9992-3

Saxena, P., \& Sonwani, S. (2020). Remediation of Ozone Pollution by Ornamental Plants in Indoor Environment. Global Journal of Environmental Science and Management, 6, No. 4. (In Press)

Sharma, S., \& Chatterjee, S. (2017). Microplastic Pollution, a Threat to Marine Ecosystem and Human Health: A Short Review. Environmental Science and Pollution Research, 24, 21530-21547. https://doi.org/10.1007/s11356-017-9910-8

Sinha, B., Sangwan, K. S., Maurya, Y., Kumar, V., Sarkar, C., Chandra, B. P., \& Sinha, V. (2015). Assessment of Crop Yield Losses in Punjab and Haryana Using Two Years of Continuous In-Situ Ozone Measurements. Atmospheric Chemistry \& Physics Discussions, 15. https://doi.org/10.5194/acpd-15-2355-2015

Stevenson, D. S., Young, P. J., Naik, V., Lamarque, J. F., Shindell, D. T., Voulgarakis, A., et al. (2013). Tropospheric Ozone Changes, Radiative Forcing and Attribution to Emissions in the Atmospheric Chemistry and Climate Model Intercomparison Project (ACCMIP). Atmospheric Chemistry \& Physics, 13, 3063-3085.

https://doi.org/10.5194/acp-13-3063-2013

Tiwari, S., Srivastava, A. K., Bisht, D. S., Parmita, P., Srivastava, M. K., \& Attri, S. D. (2013). Diurnal and Seasonal Variations of Black Carbon and PM2.5 over New Delhi, India: Influence of Meteorology. Atmospheric Research, 125, 50-62.

https://doi.org/10.1016/j.atmosres.2013.01.011

UNECE (1996). Manual on Methodologies and Criteria for Mapping Critical Levels/ Loads and Geographical Areas Where They Are Exceeded. Berlin: Umweltbundesamt.

UNECE (1999). Protocol to the 1979 Convention on Long-Range Transboundary Air Pollution to Abate Acidification, Eutrophication and Ground-Level Ozone. Gothenburg, Thirtieth Day of November. New York and Geneva: United Nations Treaty Collection.

Van Dingenen, R., Dentener, F. J., Raes, F., Krol, M. C., Emberson, L., \& Cofala, J. (2009). The Global Impact of Ozone on Agricultural Crop Yields under Current and Future Air Quality Legislation. Atmospheric Environment, 43, 604-618. https://doi.org/10.1016/j.atmosenv.2008.10.033

Wild, O., Fiore, A. M., Shindell, D. T., Doherty, R. M., Collins, W. J., Dentener, F. J., et al. (2011). Modelling Future Changes in Surface Ozone: A Parameterized Approach. Atmospheric Chemistry \& Physics Discussions, 12, 2037-2054.

https://doi.org/10.5194/acpd-11-27547-2011 